\title{
PENGARUH DIAYOGAROBIK DAN KGD AWAL TERHADAP KAPASITAS FISIK DAN KIMIAWI DARAH PENDERITA DM TIPE 2
}

\section{THE EFFECT OF DIAYOGAROBIC AND BLOOD GLUCOSE INITIAL CAPACITY AGAINST PHYSICAL AND CHEMICAL BLOOD PATIENTS WITH TYPE 2 DIABETES MELLITUS.}

\author{
Intan Imawati, B.M. Wara Kushartanti \\ Prodi Ilmu Keolahragaan PPs UNY, Universitas Negeri Yogyakarta \\ intanlukay@yahoo.com,wkushartanti@yahoo.com
}

\begin{abstract}
Abstrak
Penelitian ini bertujuan untuk mengetahui: (1) pengaruh latihan diayogarobik terhadap kapasitas fisik dan kimiawi darah, (2) perbedaan pengaruh latihan diayogarobik terhadap kapasitas fisik dan kimiawi darah antara penderita diabetes mellitus tipe 2 dengan kadar glukosa darah awal di bawah 250 $\mathrm{mg} / \mathrm{dl}$ dan di atas $250 \mathrm{mg} / \mathrm{dl}$. Metode penelitian ini adalah eksperimen. ata penelitian ini diperoleh melalui tes dan pengukuran terhadap fleksibilitas dengan menggunakan fleksometer, kekuatan otot lengan dengan Push \& Pool Dinamometer, kekuatan otot tungkai dengan Leg \& Back Dinamometer, serta kadar glukosa darah dan kadar kolesterol darah dengan Glukometer. Hasil penelitian ini menunjukkan bahwa: (1) diayogarobik terbukti dapat meningkatkan kapasitas fisik dan menurunkan kimiawi darah secara signifikan. (2) a. tidak ada perbedaan pengaruh peningkatan kapasitas fisik yang signifikan antara penderita diabetes mellitus tipe 2 dengan kadar glukosa darah $<250 \mathrm{mg} / \mathrm{dl}$ dan $>250$ $\mathrm{mg} / \mathrm{dl},(2) \mathrm{b}$. ada perbedaan pengaruh penurunan kadar glukosa darah yang signifikan antara penderita diabetes mellitus tipe 2 dengan kadar glukosa darah $<250 \mathrm{mg} / \mathrm{dl}$ dan $>250 \mathrm{mg} / \mathrm{dl}$, dengan penurunan yang lebih tinggi yaitu kadar glukosa darah $>250 \mathrm{mg} / \mathrm{dl}$, (2) c. tidak ada perbedaan pengaruh penurunan kadar kolesterol darah yang signifikan antara penderita diabetes mellitus tipe 2 dengan kadar glukosa darah $<250 \mathrm{mg} / \mathrm{dl}$ dan $>250 \mathrm{mg} / \mathrm{dl}$. Latihan diayogarobik memberikan pengaruh yang baik terhadap peningkatan kapasitas fisik dan penurunan kimiawi darah.
\end{abstract}

Kata Kunci: Latihan diayogarobik, kadar glukosa darah, kapasitas fisik, kimiawi darah, diabetes mellitus tipe 2 .

\begin{abstract}
This research is aimed to determine: (1) the effect of diayogarobic toward physical capacity and blood chemical, (2) the differences of the effect of diayogarobic practice toward physical capacity and blood chemistr between type 2 diabetes mellitus patients with initial blood glucose levels below $250 \mathrm{mg} / \mathrm{dl}$ and above $250 \mathrm{mg} / \mathrm{dl}$. The methodology of this research is experiment. All of research data is gained through test and measuring the flexibility of using fleksometer, arm muscle strength with Push \& Pool Dynamometer, leg muscle strength with Leg and Back Dynamometer, as well as blood glucose and blood cholesterol levels with Glukometer. The research result shows that: (1) diayogarobic is proven could increase physics capacity and reduce blood chemistry significantly, (2) a. there is no difference in the effect of a significant increase in physical capacity among patients with type 2 diabetes mellitus with blood glucose levels $<250 \mathrm{mg} / \mathrm{dl}$ and $>250 \mathrm{mg} / \mathrm{dl}$, (2) $\mathrm{b}$. there are differences influence blood glucose levels decrease significantly between patients with type 2 diabetes mellitus with blood glucose levels $<250 \mathrm{mg} / \mathrm{dl}$ and $>250 \mathrm{mg} / \mathrm{dl}$, with the decline in higher blood glucose levels are > $250 \mathrm{mg} / \mathrm{dl}$, (2) c. there is no difference in the effect of a decrease in blood cholesterol levels significantly between patients with type 2 diabetes mellitus with blood glucose levels $<250 \mathrm{mg} / \mathrm{dl}$ and $>250 \mathrm{mg} / \mathrm{dl}$. Diayogarobic practice gives good influence towards enhancement of physical capacity and a decrease in blood chemistry.
\end{abstract}

Keywords: diayogarobic practice, blood glucose level, phisical capacity, chemical blood, type 2 diabetes mellitus. 


\section{Pendahuluan}

Gerak adalah ciri kehidupan. Tiada hidup tanpa gerak. Apa guna hidup apabila tidak mampu bergerak. Memelihara gerak adalah mempertahankan hidup, meningkatkan kemampuan gerak adalah meningkatkan kualitas hidup. Oleh karena itu bergeraklah untuk lebih hidup, jangan hanya bergerak karena masih hidup. Kesibukan dalam kehidupan duniawi yang serba cepat dan serba mesin sering menyebabkan orang menjadi kurang gerak, diiringi stres yang dapat mengundang penyakit seperti jantung, tekanan darah tinggi, stroke maupun diabetes mellitus.

Tubuh manusia mempunyai kadar gula yang bersumber dari makanan yang biasa dikonsumsi. Nilai normal gula yang ada di dalam darah manusia itu mencapai 70-140 mg/dl, jika kadar gula melebihi normal atau di atas ratarata maka terjadi kelainan di dalam tubuh yang berkaitan dengan pankreas dan hormon insulin (Sari, 2012, p.4). Fungsi pankreas dalam susunan organ manusia untuk mengatur kadar gula darah agar selalu berada dibatas normal karena jika melebihi normal gula-gula tersebut akan meracuni sistem yang ada. Pankreas yang di dalamnya terdapat sel-sel beta mengalami kekurangan dalam memproduksi insulin sehingga timbulah gejala-gejala mudah lelah, kemudian kadar glukosa yang berlebihan tersebut dikeluarkan melalui ginjal bersama urin.

Gula memiliki sifat menarik air sehingga penderita banyak buang air kecil dan selalu merasa kehausan. Tetapi ada saatnya ketika pankreas tidak bisa menyebarluaskan insulin yang telah dibentuk untuk sel-sel karena adanya hambatan yang menghalangi karena hal tersebut gula tidak bisa masuk ke dalam sel dan akhirnya gula di dalam alirah darah tetap tinggi. Diabetes mellitus (DM) merupakan gangguan kontrol kadar glukosa darah (KGD) yang dapat menimbulkan komplikasi serius pada pembuluh darah dan syaraf sehingga berpotensi mengganggu kinerja hampir semua organ dalam tubuh.

Sejarah tentang penyakit tersebut dimulai sejak tahun $1550 \mathrm{SM}$, pada saat Sarjana Ebers dari Jerman menemukan papyrus Mesir Kuno yang menggambarkan penyakit diabetes mellitus. Penulis India menamakan dengan istilah penyakit kencing madu, hingga sekitar 200 tahun SM nama diabetes mellitus diberikan oleh Aretaeu yang artinya diabetes adalah mengalir terus dan mellitus adalah manis atau penyakit dari saluran yang keluar terus menerus seperti air pompa yang memiliki rasa manis karena adanya glukosa dalam urin. Banyak masyarakat yang berasumsi jika penyakit diabetes mellitus adalah penyakit yang tidak bisa disembuhkan, hidup sengsara karena terbebani penyakit tersebut membuat stessor pembuat stres bekerja jauh lebih meningkat, hingga tidak jarang penderita diabetes mellitus putus asa dalam menjalani kehidupannya terlebih bagi para diabetisi yang baru mengenal penyakit tersebut.

Diabetes Mellitus adalah sekelompok kelainan heterogen yang ditandai oleh kenaikan kadar gula dalam darah atau hiperglikemia (Brunner \& Suddart, 2002, p.1220). Terdapat dua jenis diabetes mellitus yakni tipe 1 (tergantung insulin) yang sering terjadi sejak masa anak dan tipe 2 (tidak tergantung insulin) yang sering muncul pada usia tua. Kadar insulin pada diabetes tipe 1 rendah sedangkan sensitivitas sel tubuh terhadap insulin pada diabetes tipe 2 rendah (Albright et al., 2000, p.1345). Pada tipe 1, diperlukan penambahan insulin yang dilakukan secara injeksi intramuscular, sedangkan pada tipe 2 diperlukan kenaikan sensitivitas selsel tubuh dengan jalan menggunakan obat oral antihipoglikemik, program latihan fisik serta penurunan berat badan (Boule et al., 2001, p.1218).

Latihan fisik merupakan bagian dari pilar utama penanganan diabetes mellitus (DM) selain edukasi, obat dan diet. Banyak penelitian menunjukkan bahwa latihan fisik bermanfaat untuk meningkatkan sensitivitas sel tubuh (mengaktifkan reseptor) terhadap insulin sehingga mengontrol kadar glukosa darah (KGD) serta mengurangi resiko komplikasi kardiovaskular dan neurologis pada penderita diabetes mellitus tipe 2. Walaupun demikian, apabila tidak dilaksanakan dengan tepat, latihan fisik pada penderita diabetes mellitus dapat menimbulkan gangguan klinis misalnya hipoglikemia maupun ketosis. Oleh karenanya, World Health Organization (WHO) tahun 1996 mengeluarkan rekomendasi kriteria latihan fisik pada diabetes mellitus (DM) tipe 2 untuk memaksimalkan manfaat klinis sekaligus meminimalkan resiko. Kriteria latihan fisik pada diabetes mellitus memenuhi kriteria FITT (frequency, intensity, time, type).

Olahraga atau aktivitas fisik adalah kebutuhan bagi semua orang, terutama orangorang yang menderita diabetes mellitus tipe 2 . Olahraga adalah serangkaian gerak raga yang 
teratur dan terencana untuk memelihara hidup, meningkatkan kualitas hidup, dan mencapai tingkat kemampuan jasmani yang sesuai dengan tujuan (Giriwijoyo, 2012, p.233).

Jenis olahraga yang dianjurkan pada penderita diabetes mellitus (DM) adalah salah satunya adalah olahraga aerobik yang bertujuan untuk meningkatkan kesehatan dan kebugaran tubuh khususnya meningkatkan fungsi dan efisiensi metabolisme tubuh. Menurut Horden et al., (2012, p.25) menyatakan olahraga yang dianjurkan bagi penderita DM adalah aerobic low impact dan rithmis, misalnya berenang, jogging, naik sepeda, dan senam, karena menggunakan semua otot-otot besar, pernapasan dan jantung. Pada senam aerobik misalnya, dari variasi gerakan-gerakan yang banyak terutama gerakan dasar pada kaki dan jalan dapat memenuhi kriteria CRIPE (continous, rhythmical, interval, progresif dan endurance) sehingga sesuai dengan tahapan. Selain pada senam aerobik, yoga adalah salah satu olahraga yang dapat dijadikan alternatif untuk penyembuhan berbagai macam penyakit misalnya diabetes mellitus tipe 2. Yoga memiliki efek detoksifikasi yang dapat mengeluarkan racun dari tubuh, sehingga memberikan bantuan dari berbagai gangguan atau penyakit di dalam tubuh. Untuk itu penggabungan antara yoga dan senam aerobik akan lebih membantu penderita diabetes mellitus tipe 2, dan diharapkan penderita dapat memperoleh kesembuhannya serta termotivasi untuk gemar berolahraga. Penggabungan antara yoga dan aerobik bagi penderita diabetes mellitus tipe 2 telah dikembangkan oleh Klinik Terapi Fisik dengan nama Diayogarobik.

Diayogarobik merupakan singkatan dari Diabetes Yoga Aerobik, karena dalam penelitian ini mengkombinasikan antara yoga dan senam aerobik. Selain untuk mencapai tujuan yang diinginkan dalam penelitian ini, diayogarobik ini dibuat berbeda dengan senam diabetes mellitus lainnya serta alunan musiknya yang mengambil atau memakai musik gamelan dari Jawa Barat (Sunda), sehingga penderita diabetes mellitus tipe 2 diharapkan lebih rileks dalam melakukan latihan ataupun terapinya. Yoga berasal dari bahasa Sansekerta "yuj" yang artinya menghubungkan atau menyatukan. Menurut Sani $(2012$, p.2) yoga adalah salah satu filsafat hidup yang dilatarbelakangi oleh ilmu pengetahuan yang universal, yakni pengetahuan tentang seni pernapasan, anatomi tubuh manusia, pengetahuan bagaimana cara mengatur pernapasan yang disertai senam atau gerak anggota badan, bagaimana cara melatih konsentrasi, menyatukan pikiran, dan lain sebagainya. Menurut Mahendra (2000, p.14) senam adalah kegiatan utama yang paling bermanfaat dalam mengembangkan komponen fisik dan kemampuan gerak (motor ability). Menurut Lynne (2002, p.9) aerobik adalah sebuah cara yang terbaik untuk berlatih sebab aerobik dapat dilakukan secara spontan atau dengan persiapan. Menurut Yonkuro (2006, p.1) senam aerobik merupakan latihan yang menggabungkan berbagai macam gerak, berirama, teratur dan terarah, serta pembawaannya yang riang.

Bertolak dari uraian tersebut maka penulis tertarik ingin mengadakan penelitian yang berjudul: Pengaruh Latihan Diayogarobik dan Kadar Glukosa Darah Awal terhadap Kapasitas Fisik dan Kimiawi Darah Penderita Diabetes Mellitus Tipe2.

Berdasarkan latar belakang masalah, maka dapat diidentifikasi masalah sebagai berikut: (1) Belum diketahuinya efek adaptasi latihan Diayogarobik terhadap fleksibilitas, kekuatan otot lengan dan kekuatan otot tungkai pada penderita diabetes mellitus tipe 2, (2) Belum diketahuinya efek adaptasi latihan Diayogobik terhadap kimiawi darah terutama kadar glukosa darah dan kadar kolesterol total darah pada penderita diabetes mellitus tipe 2, (3) Belum diketahuinya perbedaan efek adaptasi latihan Diayogarobik terhadap fleksibilitas, kekuatan otot lengan dan kekutan otot tungkai bagi penderita diabetes militus tipe 2 dengan kadar glukosa darah awal di bawah $250 \mathrm{mg} / \mathrm{dl}$ dan penderita diabetes mellitus tipe 2 kadar glukosa darah awal di atas $250 \mathrm{mg} / \mathrm{dl}$. (4) Belum diketahuinya perbedaan efek adaptasi latihan Diayogarobik terhadap kadar glukosa darah dan kadar kolesterol darah bagi penderita diabetes mellitus tipe 2 dengan kadar glukosa darah awal di bawah $250 \mathrm{mg} / \mathrm{dl}$ dan penderita diabetes mellitus tipe 2 kadar glukosa darah awal di atas 250 $\mathrm{mg} / \mathrm{dl}$.

Berdasarkan latar belakang masalah dan identifikasi masalah tersebut, dapat dirumuskan permasalahan yang akan diteliti yaitu: (1) Bagaimana pengaruh latihan Diayogarobik terhadap kapasitas fisik (fleksibilitas, kekuatan otot lengan dan kekuatan otot tungkai) dan kimiawi darah (kadar glukosa darah dan kadar kolesterol darah) pada penderita diabetes mellitus tipe 2?, (2) Adakah perbedaan pengaruh latihan Diayogarobik terhadap kapasitas fisik (fleksibilitas, kekuatan otot lengan dan kekuatan otot tungkai) dan kimiawi darah (kadar 
glukosa darah dan kadar kolesterol darah) antara penderita diabetes mellitus tipe 2 dengan kadar glukosa darah awal di bawah $250 \mathrm{mg} / \mathrm{dl}$ dan di atas $250 \mathrm{mg} / \mathrm{dl}$ ?

Berdasarkan latar belakang masalah dan identifikasi masalah yang telah diungkapkan sebelumnya, maka tujuan penelitian yang ingin dicapai adalah: (1) Untuk mengetahui efek latihan Diayogarobik selama dua bulan dengan frekuensi latihan $2 \mathrm{x}$ seminggu terhadap kapasitas fisik yang meliputi fleksibilitas, kekuatan otot lengan dan tungkai serta efek terhadap kimiawi darah yang meliputi kadar glukosa darah dan kadar kolesterol darah pada penderita diabetes mellitus tipe 2, (2) Untuk mengetahui perbedaan pengaruh latihan Diayogarobik selama dua bulan dengan frekuensi latihan $2 x$ seminggu terhadap fleksibilitas, kekuatan otot lengan dan tungkai serta kimiawi darah yang meliputi kadar glukosa darah dan kadar kolesterol darah antara penderita diabetes mellitus tipe 2 kadar glukosa darah awal di bawah 250 $\mathrm{mg} / \mathrm{dl}$ dengan penderita diabetes mellitus tipe 2 kadar glukosa darah awal di atas $250 \mathrm{mg} / \mathrm{dl}$.

Hasil penelitian ini diharapkan memberikan manfaat sebagai berikut: (1) Hasil penelitian ini dapat memberikan gambaran di bidang kesehatan kepada khalayak umum bahwa begitu besarnya manfaat olahraga dalam hal ini latihan Diayogarobik terhadap penderita diabetes mellitus tipe 2, (2) Hasil penelitian ini dapat memberikan pengetahuan tentang efek latihan Diayogarobik untuk memperbaiki kapasitas fisik seperti fleksibilitas, kekuatan otot lengan dan otot tungkai pada penderita diabetes mellitus tipe 2, (3) Hasil penelitian ini dapat memberikan pengetahuan tentang efek latihan Diayogarobik terhadap kimiawi darah yang meliputi kadar glukosa darah dan kadar kolesterol total darah pada penderita diabetes mellitus tipe 2 dengan kadar glukosa awal di atas dan di bawah $250 \mathrm{mg} / \mathrm{dl}$.

\section{Metode}

Jenis Penelitian

Metode dalam penelitian ini menggunakan metode eksperimen, dengan menggunakan tes awal (pretest) dan tes akhir (posttest). Dalam penelitian eksperimen ada perlakuan (treatment). Dengan demikian metode penelitian eksperimen dapat diartikan sebagai metode penelitian yang digunakan untuk mencari pengaruh perlakuan tertentu terhadap yang lain dalam kondisi yang terkendalikan (Sugiyono, 2008, p.72).

\section{Waktu dan Tempat Penelitian}

Tempat pelaksanaan penelitian ini dilaksanakan di halaman depan kantor kecamatan Gamping. Waktu pelaksanaan penelitian yaitu berlangsung pada awal bulan Februari sampai akhir bulan Maret tahun 2014. Subjek penelitiannya adalah penderita diabetes mellitus tipe 2 dengan kadar glukosa darah (KGD) awal di bawah $250 \mathrm{mg} / \mathrm{dl}$ dan di atas $250 \mathrm{mg} / \mathrm{dl}$.

\section{Target/Subjek Penelitian}

Menurut Sugiyono (2008, p.80) Populasi adalah wilayah generalisasi yang terdiri atas: objek atau subjek yang mempunyai kualitas dan karakteristik tertentu yang ditetapkan oleh peneliti untuk dipelajari dan kemudian ditarik kesimpulannya. Populasi dalam penelitian ini adalah anggota klub senam Prolanis di Kecamatan Gamping yang berjumlah 83 orang.

Sampel dalam penelitian ini adalah penderita diabetes mellitus tipe 2 yang berjumlah 30 orang dengan dibagi dua kelompok yaitu kadar glukosa darah (KGD) awal di bawah 250 $\mathrm{mg} / \mathrm{dl}$ dan di atas $250 \mathrm{mg} / \mathrm{dl}$. Pembagian sampel dilakukan dengan cara tes kadar glukosa darah dengan Glukometer, kemudian di dapat 13 orang mempunyai kadar glukosa darah awal di bawah $250 \mathrm{mg} / \mathrm{dl}$ dan 17 orang mempunyai kadar glukosa darah awal di atas $250 \mathrm{mg} / \mathrm{dl}$.

\section{Variabel Bebas}

Variabel bebas (independent variable) dalam penelitian ini ada 2 yaitu (1) Variabel bebas manipulatif yaitu latihan diayogarobik (2) Variabel bebas atributif (yang dikendalikan) dalam penelitian ini adalah kadar glukosa darah awal di bawah $250 \mathrm{mg} / \mathrm{dl}$ dan kadar glukosa darah di atas $250 \mathrm{mg} / \mathrm{dl}$. Latihan Diayogarobik adalah merupakan gabungan dari yoga dan senam aerobik. Yoga merupakan meditasi yaitu aliran pikiran. Meditasi dalam gerak sebab dalam melakukan gerakan yoga juga pikiran yang dilatih untuk tenang. Senam aerobik merupakan serangkaian gerak yang dipadukan dengan irama musik yang mempunyai banyak variasi gerakan dan termasuk olahraga populer dikalangan usia.

Diayogarobik ini dibuat berbeda dengan senam diabetes mellitus lainnya serta alunan musiknya yang mengambil atau memakai musik gamelan dari Jawa Barat (Sunda), sehingga penderita diabetes mellitus tipe 2 
diharapkan lebih rileks dalam melakukan latihan ataupun terapinya.

Kadar glukosa darah merupakan kadar gula monosakarida yang digunakan untuk sumber tenaga. Dalam penelitian ini kadar glukosa darah akan dicek terlebih dahulu sebelum diberikan perlakuan, dan setelah diberikan perlakuan akan dicek kembali dan kemudian dapat dilihat hasilnya. Setelah di tes dengan alat yang bernama Glukometer maka kadar glukosa darah awal dibagi menjadi dua kelompok yaitu kadar glukosa darah di atas $250 \mathrm{mg} / \mathrm{dl}$ dan kadar glukosa darah di bawah $250 \mathrm{mg} / \mathrm{dl}$.

\section{Variabel Terikat}

Variabel terikat dalam penelitian ini yaitu peningkatan kapasitas fisik dan penurunan kimiawi darah. Kapasitas fisik meliputi fleksibilitas, kekuatan otot lengan dan kekuatan otot tungkai, sedangkan kimiawi darah meliputi kadar glukosa darah dan kadar kolesterol darah. Data diperoleh dengan cara pengukuran komponen biomotor atau kapasitas fisik, pengecekan kadar glukosa darah dan kadar kolesterol total darah (kimiawi darah), Instrumen penelitian untuk mengukur komponen biomotor fleksibilitas menggunakan alat yang bernama fleksometer, untuk mengukur kekuatan otot lengan menggunakan alat Push \& Pool Dinamometer dan untuk mengukur kekuatan otot tungkai menggunakan alat Leg \& Back Dinamometer. Sedangkan untuk kadar glukosa darah dan kadar kolesterol darah menggunakan alat yang bernama Glukometer dengan merk Easy Touch GCU (Glucose, Cholesterol, UA).

\section{Teknik Pengumpulan Data}

Teknik pengumpulan data dalam penelitian ini adalah dengan metode tes sebelum (pretest) dan sesudah (posttest) diberikan perlakuan. Tes ini meliputi cek kadar glukosa darah dan kadar kolesterol darah, tes fleksibilitas, kekuatan otot lengan dan kekuatan otot tungkai.

Instrumen penelitian merupakan alat bantu yang digunakan peneliti untuk mengumpulkan data (Arikunto, 2005, p.101). Untuk dapat mengumpulkan data dengan teliti, maka diperlukan instrumen penelitian. Instrumen yang baik adalah instumen valid dan reliabel. Instrumen yang valid berarti alat ukur yang digunakan untuk mendapatkan data itu valid (dapat digunakan untuk mengukur apa yang akan diukur), sedang instrumen yang reliabel adalah instrumen yang dapat digunakan beberapa kali untuk mengukur objek yang sama akan menghasilkan data yang sama.

Instrumen dalam penelitian ini adalah menggunakan instrumen tes pengukuran komponen biomotor atau kapasitas fisik, pengecekan kadar glukosa darah dan kadar kolesterol total darah (kimiawi darah), Instrumen penelitian untuk mengukur komponen biomotor fleksibilitas menggunakan alat yang bernama fleksometer, untuk mengukur kekuatan otot lengan menggunakan alat Push \& Pool Dinamometer dan untuk mengukur kekuatan otot tungkai menggunakan alat Leg \& Back Dinamometer. Sedangkan untuk kadar glukosa darah dan kadar kolesterol darah menggunakan alat yang bernama Glukometer dengan merk Easy Touch GCU (Glucose, Cholesterol, UA).

\section{Teknik Analisis Data}

Dalam penelitian ini analisis data yang digunakan yaitu analisis statistik uji perpasangan paired $t$-tes dan independen $t$-tes. Data yang dianalisis adalah data tes kapasitas fisik (fleksibilitas, kekuatan otot lengan dan kekutan otot tungkai) dan kimiawi darah (kadar glukosa darah dan kolesterol darah). Setelah data terkumpul kemudian dilakukan pengolahan data. Teknik analisis data dalam penelitian ini menggunakan uji hipotesis dengan uji t. Sebelum dilakukan uji hipotesis terlebih dahulu dilakukan uji prasyarat yang meliputi uji normalitas dan homogenitas data. Keputusan menerima atau menolak hipotesis pada taraf signifikansi $5 \%$, untuk menganalisis data digunakan bantuan komputer program SPSS 20.0 for Windows Evaluation Version.

\section{Uji Normalitas Data}

Teknik yang digunakan dalam uji normalitas adalah uji Kolmogorov Smirnow (Sudjana, 2005, p.466). Uji normalitas ini dilakukan untuk mengetahui apakah sampel yang digunakan dalam penelitian berdistribusi normal atau tidak.

\section{Uji Homogenitas}

Pengujian homogenitas variansi menggunakan uji Levene Test (Sudjana, 2005, p.261). Pengujian dilakukan terhadap dua kelompok perlakuan eksperimen. Hasil dari perbandingan tersebut adalah untuk menguji apakah kedua kelompok perlakuan berasal dari populasi yang memiliki variansi homogen atau tidak. Setelah dilakukan uji normalitas dan uji homogenitas variansi, maka persyaratan untuk 
penggunaan t-tes sampel berpasangan (paired $t$ - tes), dan sampel independen (independent $t$ tes) dalam analisis data sudah dipenuhi.

Uji Hipotesis

Untuk menguji hipotesis dilakukan dengan menggunakan uji t-tes sampel berpasangan (paired t-tes), dan sampel independen (independent t-tes). Software SPSS version 20.0 for windows dengan taraf signifikansi $5 \%$ atau 0,05 .

\section{Progam Latihan}

Aktivitas fisik yang bermanfaat untuk kesehatan penderita diabetes mellitus tipe 2 sebaiknya memenuhi kriteria FITT (frequency, intensity, time, type). Frekuensi adalah seberapa sering aktivitas dilakukan, berapa hari dalam seminggu. Intensitas adalah seberapa keras suatu aktivitas dilakukan. Biasanya diklasifikasikan menjadi intensitas rendah, sedang, dan tinggi. Waktu mengacu pada durasi, seberapa lama suatu aktivitas dilakukan dalam satu pertemuan, sedangkan jenis aktivitas adalah jenisjenis aktivitas fisik yang dilakukan.

Jenis akivitas fisik atau olahraga dalam penelitian ini adalah latihan diayogarobik. Program latihan dengan gabungan antara yoga dan senam aerobik dilakukan dengan frekuensi $2 \mathrm{x}$ seminggu. Dilaksanakan selama 8 minggu, dimulai awal bulan Februari sampai akhir Maret tahun 2014. Intensitas latihan rendah-sedang. Diayogarobik menggunakan intensitas sedang dikarenakan latihan ini tidak bertujuan untuk olahraga prestasi melainkan untuk terapi pada penderita diabetes mellitus tipe 2. Durasi latihan selama 30 menit. Program latihan fisik untuk penderita diabetes seperti halnya pada orang normal yakni $45 \%$ sampai dengan $85 \%$ kapasitas fungsional. Walaupun demikian pada diabetes mellitus tipe 2, intensitas latihan fisik diarahkan pada tingkat $40 \%$ sampai dengan $60 \%$ karena frekuensi dan durasi latihan yang cukup tinggi. Pada kebanyakan penderita diabetes, intensitas latihan dapat didasarkan pada denyut nadi istirahat, akan tetapi pada penderita dengan neuropati otonom hal ini harus diperhatikan mengingat pada keadaan ini terjadi hambatan untuk meningkatkan denyut jantung, pada keadaan ini rating of perceived exertion (RPE) lebih cocok untuk dipergunakan dalam menentukan intensitas latihan (Boule et al., 2001, p.1218). Menu progam latihan diayogarobik pada penderita diabetes mellitus tipe 2 .

\begin{tabular}{ll}
\hline Tujuan & $\begin{array}{l}\text { : meningkatkan kapasitas fisik dan } \\
\text { menurunkan kadar glukosa darah } \\
\text { dan kadar kolesterol darah }\end{array}$ \\
\hline Intensitas & $:$ Rendah-Sedang $(40 \%-60 \%)$ \\
\hline Volume & $: 30$ menit/sesi. \\
\hline Recovery & $: 15$ detik \\
\hline Durasi & $: 30$ menit \\
\hline Frekuensi & $: 2 x$ seminggu \\
\hline
\end{tabular}

\section{Hasil Penelitian dan Pembahasan}

Data yang telah dikumpulkan sebelum dianalisis terlebih dahulu dilakukan uji persyaratan, yang meliputi uji normalitas dengan menggunakan Kolmogorof Smirnov, dan uji homogenitas dengan uji Levene Test. (1) Uji normalitas, Uji normalitas dilakukan terhadap 30 subjek penderita diabetes mellitus tipe 2 dengan kadar glukosa darah awal di bawah dan di atas $250 \mathrm{mg} / \mathrm{dl}$, analisis dilakukan dengan program software SPSS version 20.0 for windows dengan taraf signifikansi $5 \%$ atau 0,05 .

Pada data hasil 30 subjek penderita diabetes melitus tipe 2 dengan kadar glukosa darah awal di bawah $250 \mathrm{mg} / \mathrm{dl}$ dan di atas 250 $\mathrm{mg} / \mathrm{dl}$ tes awal didapat dari hasil uji normalitas data yang dilakukan pada kadar glukosa darah terdapat tingkat signifikan pretest sebesar 0,761 ini berarti $\mathrm{p}>0,05$. Pada kadar kolesterol darah terdapat tingkat signifikan pretest sebesar 0,825 ini berarti $\mathrm{p}>0,05$ yang berarti bahwa $\mathrm{H}_{0}$ diterima dan $\mathrm{H}_{\mathrm{I}}$ ditolak (berdistribusi Normal).

Pada kapasitas fisik yang meliputi fleksibilitas, kekuatan otot lengan dan kekutan otot tungkai. Fleksibilitas terdapat tingkat signifikan pretest sebesar 0,505 ini berarti $\mathrm{p}>0,05$. Kemudian untuk kekuatan otot lengan terdapat tingkat signifikan pretest sebesar 0,972 ini berarti $\mathrm{p}>0,05$ yang berarti bahwa $\mathrm{H}_{0}$ diterima dan $\mathrm{H}_{\mathrm{I}}$ ditolak (berdistribusi Normal).

Selanjutnya pada kekuatan otot tungkai terdapat tingkat signifikan pretest sebesar 0,091 ini berarti $\mathrm{p}>0,05$ Artinya data pada tes awal 30 subjek penderita diabetes mellitus tipe 2 dengan kadar glukosa darah awal di bawah dan di atas $250 \mathrm{mg} / \mathrm{dl}$ terbukti berdistribusi nor-mal dan telah memenuhi uji prasyarat, sehingga untuk penggunaan paired t-tes dan independen t-tes dalam analisis data sudah dipenuhi. Artinya analisis statistik uji parametrik dapat dilanjutkan.

Tabel 1. Data Normalitas 30 Subjek Penderita Diabetes MellitusTipe 2 (Pretest). 


\begin{tabular}{llll}
\hline & \multicolumn{1}{c}{ Variabel } & \multicolumn{1}{c}{ P } & \multicolumn{1}{c}{ Ket } \\
\hline 1. & Kadar Glukosa Darah & 00,761 & Normal \\
2 & Kadar Kolesterol Darah & 00,825 & Normal \\
3 & Fleksibilitas & 0,505 & Normal \\
& & & \\
4 & Kekuatan otot lengan & 0,972 & Normal \\
5 & Kekuatan otot tungkai & 0,091 & Normal \\
\hline
\end{tabular}

Tabel 2. Data Normalitas 30 Subjek Penderita Diabetes Mellitus Tipe 2 (Posttest).

\begin{tabular}{llcc}
\hline & \multicolumn{1}{c}{ Variabel } & \multicolumn{1}{c}{ P } & Ket \\
\hline 1 & Kadar Glukosa Darah & 00,490 & Normal \\
2 & Kadar Kolesterol Darah & 00,927 & Normal \\
3 & Fleksibilitas & 0,496 & Normal \\
4 & Kekuatan otot lengan & 0,849 & Normal \\
5 & Kekuatan otot tungkai & 0,570 & Normal \\
\hline
\end{tabular}

(2) Uji homogenitas dilakukan untuk menguji persamaan beberapa sampel yaitu homogen atau tidak. Uji homogenitas dimaksudkan menguji kesamaan varian antara kelompok 1 dan kelompok 2. Uji homogenitas pada penelitian ini adalah uji Levene Test.

Tabel 3. Data Homogenitas 30 Subjek Penderita Diabetes Mellitus Tipe 2 (Pretest).

\begin{tabular}{llcl}
\hline No & \multicolumn{1}{c}{ Variabel } & P & \multicolumn{1}{c}{ Ket } \\
\hline 1 & Kadar Glukosa Darah & 00,089 & Homogen \\
2 & Kadar Kolesterol Darah & 00,567 & Homogen \\
3 & Fleksibilitas & 0,666 & Homogen \\
4 & Kekuatan otot lengan & 0,358 & Homogen \\
5 & Kekuatan otot tungkai & 0,520 & Homogen \\
\hline
\end{tabular}

Tabel 4. Data Homogenitas 30 Subjek Penderita Diabetes Mellitus Tipe 2 (Posttest).

\begin{tabular}{llll}
\hline & \multicolumn{1}{c}{ Variabel } & \multicolumn{1}{c}{ P } & \multicolumn{1}{c}{ Ket } \\
\hline 1. & Kadar Glukosa Darah & 0,139 & Homogen \\
2. & Kadar Kolesterol Darah & 00,550 & Homogen \\
3 & Fleksibilitas & 0,960 & Homogen \\
4 & Kekuatan otot lengan & 0,153 & Homogen \\
5 & Kekuatan otot tungkai & 0,540 & Homogen \\
\hline
\end{tabular}

Kriteria pengambilan keputusan adalah apabila $\mathrm{p}>0,05$, maka berarti dapat disimpulkan bahwa data sampel tersebut homogen. Demikian sebaliknya apabila $\mathrm{p}<0,05$, berarti dapat disimpulkan bahwa data sampel tersebut memiliki varian yang tidak homogen. Berdasarkan analisis statistik uji homogenitas yang telah dilakukan dengan menggunakan uji Levene Test. Pada kadar glukosa darah diperoleh nilai signifikansi pretest sebesar 0,089 dan posttest sebesar 0,139 ini berarti $\mathrm{p}>0,05=$ Homogen. Pada kadar kolesterol darah diperoleh nilai sig- nifikan pretest sebesar 0,567 dan posttest sebesar 0,550 ini berarti $\mathrm{p}>0,05=$ Homogen .

Selanjutnya pada kapasitas fisik yang meliputi fleksibilitas, kekuatan otot lengan dan kekuatan otot tungkai. Fleksibilitas diperoleh nilai pretest sebesar 0,666 dan posttest sebesar 0,960 ini berarti $p>0,05=$ Homogen. Kemudian pada kekuatan otot lengan diperoleh nilai pretest sebesar 0,358 dan posttest sebesar 0,153 ini berarti $\mathrm{p}>0,05=$ Homogen. Demikian juga dengan kekuatan otot tungkai didapat nilai signifikansi pretest sebesar 0,520 dan posttest 0,540 ini berarti $\mathrm{p}>0,05=$ Homogen. Artinya data pada tes awal dan tes akhir 30 subjek penderita diabetes mellitus tipe 2 dengan kadar glukosa darah awal di bawah dan di atas 250 $\mathrm{mg} / \mathrm{dl}$ memiliki varian yang homogen dan telah memenuhi uji prasyarat, sehingga untuk penggunaan paired t-tes dan independen t-tes dalam analisis data sudah dipenuhi. Artinya analisis statistik uji parametrik dapat dilanjutkan.

\section{Pengujian Hipotesis}

Hipotesis dalam penelitian ini diuji dengan menggunakan uji $t$-tes sampel berpasangan (paired t-tes) dan analisis menggunakan uji $t$-tes sampel independen (independent $t$-tes).

\section{Hipotesis 1}

Hipotesis pertama yang diajukan dalam penelitian ini adalah sebagai berikut: ada penurunan kimiawi darah yang meliputi kadar glukosa darah dan kadar kolesterol darah serta peningkatan kapasitas fisik yang meliputi fleksibilitas, kekuatan otot lengan dan kekuatan otot tungkai bagi penderita diabetes mellitus tipe 2 dengan kadar glukosa darah awal di bawah dan di atas $250 \mathrm{mg} / \mathrm{dl}$ setelah mengikuti latihan diayogarobik.

Jika $\alpha=0,05$ lebih besar atau sama dengan nilai sig. Atau $[\alpha=0,05 \geq \operatorname{sig}]$, maka Ho diterima, artinya tidak ada penurunan kadar glukosa darah yang signifikan bagi penderita diabetes mellitus tipe 2 dengan kadar glukosa darah awal di bawah dan di atas $250 \mathrm{mg} / \mathrm{dl}$. Jika $\alpha=0,05$ lebih kecil atau sama dengan nilai sig. Atau $[\alpha=0,05 \leq s i g]$, maka ${ }_{\text {но }}$ ditolak, artinya ada penurunan kadar glukosa darah yang signifikan bagi penderita diabetes mellitus tipe 2 dengan kadar glukosa darah awal di bawah dan di atas $250 \mathrm{mg} / \mathrm{dl}$.

Hasil statistik t diperoleh 12.794 dan pada taraf sig diperoleh sebesar 0,000 $<0,05$ dengan demikian hipotesis yang berbunyi ada penurunan kadar glukosa darah bagi penderita 
diabetes mellitus tipe 2 dengan kadar glukosa darah awal di bawah dan di atas $250 \mathrm{mg} / \mathrm{dl}$ setelah mengikuti latihan diayogarobik. Hal ini berarti Ho ditolak artinya ada pengaruh penurunan kadar glukosa darah yang signifikan bagi penderita diabetes mellitus tipe 2 setelah mengkuti program latihan Diayogarobik.

Jika $\alpha=0,05$ lebih besar atau sama dengan nilai sig. Atau $[\alpha=0,05 \geq \operatorname{sig}]$, maka Ho diterima, artinya tidak ada penurunan kadar kolesterol darah yang signifikan bagi penderita diabetes mellitus tipe 2 dengan kadar glukosa darah awal di bawah dan di atas $250 \mathrm{mg} / \mathrm{dl}$. Jika $\alpha=0,05$ lebih kecil atau sama dengan nilai sig. Atau $[\alpha=0,05 \leq \operatorname{sig}]$, maka $\mathrm{H}_{0}$ ditolak, artinya ada penurunan kadar kolesterol darah yang signifikan bagi penderita diabetes mellitus tipe 2 dengan kadar glukosa darah awal di bawah dan di atas $250 \mathrm{mg} / \mathrm{dl}$.

Hasil statistik t diperoleh 9.775 dan pada taraf sig diperoleh sebesar $0,000<0,05$ dengan demikian hipotesis yang berbunyi ada penurunan kadar kolesterol darah bagi penderita diabetes mellitus tipe 2 dengan kadar glukosa darah awal di bawah dan di atas $250 \mathrm{mg} / \mathrm{dl}$ setelah mengikuti latihan diayogarobik. Hal ini berarti Ho ditolak artinya ada pengaruh penurunan kadar kolesterol darah yang signifikan bagi penderita diabetes mellitus tipe 2 setelah mengkuti program latihan Diayogarobik.

Jika $\alpha=0,05$ lebih besar atau sama dengan nilai sig. Atau $[\alpha=0,05 \geq \operatorname{sig}]$, maka Ho diterima, artinya tidak peningkatan kapasias fisik (fleksibilitas, kekuatan otot lengan, dan kekuatan otot tungkai) yang signifikan bagi penderita diabetes mellitus tipe 2 dengan kadar glukosa darah awal di bawah dan di atas 250 $\mathrm{mg} / \mathrm{dl}$. Jika $\alpha=0,05$ lebih kecil atau sama dengan nilai sig. Atau $[\alpha=0,05 \leq s i g]$, maka $\mathrm{H}_{0}$ ditolak, artinya ada peningkatan kapasias fisik (fleksibilitas, kekuatan otot lengan, dan kekuatan otot tungkai) yang signifikan bagi penderita diabetes mellitus tipe 2 dengan kadar glukosa darah awal di bawah dan di atas $250 \mathrm{mg} / \mathrm{dl}$.

Hasil statistik $\mathrm{t}$ diperoleh -14.519 (kekuatan otot lengan), -9.412 (kekuatan otot tungkai), -6.416 (fleksibilitas) dan pada taraf sig diperoleh sebesar $0,000<0,05$ dengan demikian hipotesis yang berbunyi ada peningkatan kapasitas fisik (fleksibilitas, kekuatan otot lengan dan kekuatan otot tungkai) bagi penderita diabetes mellitus tipe 2 dengan kadar glukosa darah awal di bawah dan di atas $250 \mathrm{mg} / \mathrm{dl}$ setelah mengikuti latihan diayogarobik. Hal ini berarti Ho ditolak artinya ada pengaruh pening- katan kapasitas fisik (fleksibilitas, kekuatan otot lengan dan kekuatan otot tungkai) yang signifikan bagi penderita diabetes mellitus tipe 2 setelah mengkuti program latihan Diayogarobik.

\section{Hipotesis 2}

Hipotesis kedua yang diajukan dalam penelitian ini adalah sebagai berikut: ada perbedaan penurunan kimiawi darah (kadar glukosa darah dan kadar kolesterol darah) dan peningkatan kapasitas fisik (fleksibilitas, kekuatan otot lengan dan tungkai) antara penderita diabetes mellitus tipe 2 kadar glukosa darah yang di bawah $250 \mathrm{mg} / \mathrm{dl}$ dengan penderita diabetes mellitus tipe 2 kadar glukosa darah di atas 250 $\mathrm{mg} / \mathrm{dl}$ setelah mengikuti latihan diayogarobik.

Jika $\alpha=0,05$ lebih besar atau sama dengan nilai sig. Atau $[\alpha=0,05 \geq \operatorname{sig}]$, maka Ho diterima, artinya tidak ada perbedaan penurunan kadar glukosa darah antara penderita diabetes mellitus tipe 2 kadar glukos darah yang di bawah $250 \mathrm{mg} / \mathrm{dl}$ dengan penderita diabetes mellitus tipe 2 kadar glukosa darah di atas 250 $\mathrm{mg} / \mathrm{dl}$.

Jika $\alpha=0,05$ lebih kecil atau sama dengan nilai sig. Atau $[\alpha=0,05 \leq s i g]$, maka $\mathrm{H}_{0}$ ditolak, artinya ada perbedaan penurunan kadar glukosa darah antara penderita diabetes mellitus tipe 2 yang kadar glukosa darah di bawah 250 $\mathrm{mg} / \mathrm{dl}$ dengan penderita diabetes mellitus tipe 2 yang kadar glukosa darah di atas $250 \mathrm{mg} / \mathrm{dl}$.

Hasil statistik t diperoleh -5.764 dan Pada taraf sig diperoleh sebesar $0,000<0,05$ dengan demikian hipotesis yang berbunyi ada perbedaan penurunan kadar glukosa darah antara penderita diabetes mellitus tipe 2 kadar glukosa darah yang di bawah $250 \mathrm{mg} / \mathrm{dl}$ dengan penderita diabetes mellitus tipe 2 kadar glukosa darah di atas $250 \mathrm{mg} / \mathrm{dl}$ setelah mengikuti latihan Diayogarobik, maka Ho ditolak artinya ada perbedaan penurunan kadar glukosa darah yang signifikan antara penderita diabetes mellitus tipe 2 kadar glukosa darah yang di bawah 250 $\mathrm{mg} / \mathrm{dl}$ dengan penderita diabetes mellitus tipe 2 kadar glukosa darah di atas $250 \mathrm{mg} / \mathrm{dl}$.

Jika $\alpha=0,05$ lebih besar atau sama dengan nilai sig. Atau $[\alpha=0,05 \geq \operatorname{sig}]$, maka Ho diterima, artinya tidak ada perbedaan penurunan kadar kolesterol darah antara penderita diabetes mellitus tipe 2 kadar glukosa darah yang di bawah $250 \mathrm{mg} / \mathrm{dl}$ dengan penderita diabetes mellitus tipe 2 kadar glukosa darah di atas 250 $\mathrm{mg} / \mathrm{dl}$.

Jika $\alpha=0,05$ lebih kecil atau sama dengan nilai sig. Atau $\left[\alpha=0,05 \leq\right.$ sig], maka $\mathrm{H}_{0}$ 
ditolak, artinya ada perbedaan penurunan kadar kolesterol darah antara penderita diabetes mellitus tipe 2 kadar glukosa darah yang di bawah $250 \mathrm{mg} / \mathrm{dl}$ dengan penderita diabetes mellitus tipe 2 kadar glukosa darah di atas $250 \mathrm{mg} / \mathrm{dl}$.

Hasil statistik $\mathrm{t}$ diperoleh 0,382 dan pada taraf sig diperoleh sebesar 0,705 >0,05 dengan demikian hipotesis yang berbunyi ada perbedaan penurunan kadar kolesterol darah antara penderita diabetes mellitus tipe 2 kadar glukosa darah yang di bawah $250 \mathrm{mg} / \mathrm{dl}$ dengan penderita diabetes mellitus tipe 2 kadar glukosa darah di atas $250 \mathrm{mg} / \mathrm{dl}$ setelah mengikuti latihan Diayogarobik, maka Ho diterima artinya tidak ada perbedaan penurunan kadar kolesterol darah yang signifikan antara penderita diabetes mellitus tipe 2 kadar glukosa darah yang di bawah $250 \mathrm{mg} / \mathrm{dl}$ dengan penderita diabetes mellitus tipe 2 kadar glukosa darah di atas 250 $\mathrm{mg} / \mathrm{dl}$

Jika $\alpha=0,05$ lebih besar atau sama dengan nilai sig. Atau $[\alpha=0,05 \geq \operatorname{sig}]$, maka Ho diterima, artinya tidak ada perbedaan peningkatan kapasitas fisik (fleksibilitas, kekuatan otot lengan dan kekuatan otot tungkai) antara penderita diabetes mellitus tipe 2 kadar glukosa darah yang di bawah $250 \mathrm{mg} / \mathrm{dl}$ dengan penderita diabetes mellitus tipe 2 kadar glukosa darah di atas $250 \mathrm{mg} / \mathrm{dl}$. Jika $\alpha=0,05$ lebih kecil atau sama dengan nilai sig. Atau $[\alpha=0,05 \leq$ sig $]$, maka $\mathrm{H}_{0}$ ditolak, artinya ada perbedaan peningkatan kapasitas fisik (fleksibilitas, kekuatan otot lengan dan kekuatan otot tungkai) antara penderita diabetes mellitus tipe 2 kadar glukosa darah yang di bawah $250 \mathrm{mg} / \mathrm{dl}$ dengan penderita diabetes mellitus tipe 2 kadar glukosa darah di atas $250 \mathrm{mg} / \mathrm{dl}$.

Pada kekuatan otot lengan hasil statistik t diperoleh $-0,570$ dan pada taraf sig diperoleh sebesar 0,573>0,05. Kemudian pada kekuatan otot tungkai hasil statistik $\mathrm{t}$ diperoleh 1.623 dan taraf sig diperoleh sebesar 0,116 > 0,05 . Selanjutnya fleksibilitas hasil statistik $t$ diperoleh -0,032 dan taraf sig diperoleh sebesar $0,975>0,05$ dengan demikian hipotesis yang berbunyi ada perbedaan peningkatan kapasitas fisik (fleksibilitas, kekuatan otot lengan dan kekuatan otot tungkai) antara penderita diabetes mellitus tipe 2 kadar glukosa darah yang di bawah $250 \mathrm{mg} / \mathrm{dl}$ dengan penderita diabetes mellitus tipe 2 kadar glukosa darah di atas 250 $\mathrm{mg} / \mathrm{dl}$ setelah mengikuti latihan Diayogarobik, maka Ho diterima artinya tidak ada perbedaan peningkatan kapasitas fisik (fleksibilitas, kekuatan otot lengan dan kekuatan otot tungkai) yang signifikan antara penderita diabetes mellitus tipe 2 kadar glukosa darah yang di bawah $250 \mathrm{mg} / \mathrm{dl}$ dengan penderita diabetes mellitus tipe 2 kadar glukosa darah di atas $250 \mathrm{mg} / \mathrm{dl}$.

\section{Pembahasan Hasil Penelitian}

Hasil Pengaruh Latihan Diayogarobik dan Kadar Glukosa Darah Awal Terhadap Peningkatan Kapasitas Fisik dan Penurunan Kimiawi Darah pada Penderita Diabetes Mellitus Tipe 2.

Berdasarkan hasil analisis 30 subjek penderita Diabetes Mellitus Tipe 2 menunjukan bahwa hasil peningkatan kapasitas fisik yang meliputi fleksibilitas, kekuatan otot lengan dan kekuatan otot tungkai setelah melakukan program latihan diayogarobik selama 2 bulan dengan frekuensi latihan 2 kali seminggu dan durasi 30 menit di daerah kecamatan Gamping, Sleman Yogyakarta menunjukkan bahwa pengujian hipotesis pertama ternyata ada peningkatan kapasitas fisik yang signifikan bagi penderita diabetes mellitus tipe 2 .

Diayogarobik apabila ditinjau dari segi gerakannya memiliki beberapa manfaat yaitu menyehatkan tubuh, meningkatkan semangat untuk melakukan aktivitas, menguatkan otototot tubuh dan tidak kaku, menstabilkan tubuh dan lain sebagainya. Penderita diabetes mellitus tipe 2 biasanya disebabkan karena keturunan, gaya hidup yang tidak sehat, kegemukan, kurang olahraga, terlalu banyak makan dengan gizi yang tidak seimbang. Gejala yang menyertai diabetes mellitus tipe 2 yang biasa dikeluhkan adalah cepat lelah, kurang gairah kerja, mudah mengantuk, dan rasa kesemutan di tangan maupun ditungkai (Sari, 2012, p.10).

Selain terbukti dapat meningkatkan kapasitas fisik yang meliputi fleksibilitas, kekuatan otot lengan dan kekuatan otot tungkai. Gerakan-gerakan diayogarobik juga bermanfaat untuk menurunkan kimiawi darah yang meliputi kadar glukosa darah dan kadar kolesterol darah. Gerakan yoga yang dapat menurunkan gula darah, kolesterol jahat, menurunkan berat badan, dan memperbaiki sensitivitas pada insulin. Sedangkan gerakan senam aerobik menggunakan otot besar dilakukan secara terus-menerus dan berirama dapat meningkatkan sensitivitas reseptor insulin (Horden et. al., 2012, p.25). Peningkatan reseptor tersebut mampu meningkatkan transfer glukosa ke sel, sehingga terjadi penurunan kadar glukosa darah pada penderita diabetes mellitus tipe 2 . 
Berdasarkan kajian tersebut, tampak bahwa latihan diayogarobik dapat berpengaruh untuk meningkatkan fleksibilitas, kekuatan otot lengan dan kekuatan otot tungkai serta dapat menurunkan kadar glukosa darah dan kadar kolesterol darah. Kebenaran teori di atas juga diperkuat dengan hasil analisis data dalam penelitian ini yaitu: pada taraf sig diperoleh sebesar $0,000<0,05$ jadi terbukti ada peningkatan fleksibilitas, kekuatan otot lengan, dan kekuatan otot tungkai serta menurunkan kadar glukosa darah dan kadar kolesterol darah bagi penderita diabetes mellitus tipe 2 setelah mengkuti program latihan Diayogarobik.

Hasil Perbedaan Pengaruh Latihan Diayogarobik Terhadap Peningkatan Kapasitas Fisik dan Penurunan Kimiawi Darah pada Penderita Diabetes Mellitus Tipe 2 antara Kadar Glukosa Darah di bawah $250 \mathrm{mg} / \mathrm{dl}$ dengan di atas $250 \mathrm{mg} / \mathrm{dl}$.

Berdasarkan hasil analisis 30 subjek penderita Diabetes Mellitus Tipe 2 yang dibagi menjadi 2 kelompok yaitu penderita diabetes mellitus tipe 2 dengan kadar glukosa darah di bawah $250 \mathrm{mg} / \mathrm{dl}$ dan penderita diabetes mellitus tipe 2 dengan kadar glukosa darah di atas $250 \mathrm{mg} / \mathrm{dl}$, menunjukan bahwa hasil perbeda-an peningkatan kapasitas fisik yang meliputi fleksibilitas, kekuatan otot lengan dan kekuatan otot tungkai setelah melakukan progam latihan diayogarobik selama 2 bulan dengan frekuensi latihan 2 kali seminggu dan durasi 30 menit di daerah kecamatan Gamping, Sleman Yogyakarta menunjukkan bahwa pengujian hipotesis kedua ternyata tidak ada perbedaan peningkatan kapasitas fisik (fleksibilitas, kekuatan otot lengan dan kekuatan otot tungkai) yang signifikan bagi penderita diabetes mellitus tipe 2 antara kadar glukosa darah di bawah $250 \mathrm{mg} / \mathrm{dl}$ dengan yang di atas $250 \mathrm{mg} / \mathrm{dl}$.

Penderita diabetes mellitus tipe 2 antara kadar glukosa darah di bawah $250 \mathrm{mg} / \mathrm{dl}$ dengan kadar glukosa darah di atas $250 \mathrm{mg} / \mathrm{dl}$ sama-sama diberikan perlakuan diayogarobik dengan frekuensi dan durasi yang sama. Jika dilihat dari kadar glukosa darah awal, untuk penderita diabetes mellitus tipe 2 dengan kadar glukosa darah di bawah $250 \mathrm{mg} / \mathrm{dl}$ merupakan penderita diabetes kategori lebih ringan dibandingkan dengan penderita diabetes dengan kadar glukosa darah di atas $250 \mathrm{mg} / \mathrm{dl}$.

Penderita diabetes ringan maupun berat sama-sama memiliki gejala cepat lelah, mudah mengantuk, otot menjadi lemah karena glukosa tidak mampu masuk ke dalam sel otot. Latihan jasmani pada diabetes mellitus tipe 2 berperan utama dalam pengaturan kadar glukosa darah. Jika diabetes terkontrol tanpa komplikasi ketosis, latihan akan menurunkan kadar gula darah sehingga kebutuhan terhadap insulin eksogen menurun. Sebaliknya apabila kadar gula darah tidak terkontrol atau insulin tidak cukup tersedia sebelum latihan fisik dilakukan, transport glukosa ke sel otot akan terhambat sehingga glukosa tidak tersedia sebagai sumber energi (Gardner et al., 2001, p.755).

Selanjutnya untuk perbedaan penurunan kadar glukosa darah penderita diabetes mellitus tipe 2 di bawah $250 \mathrm{mg} / \mathrm{dl}$ dengan di atas $250 \mathrm{mg} / \mathrm{dl}$ menunjukkan bahwa pengujian hipotesis kedua ternyata ada perbedaan penurunan kadar glukosa darah di bawah $250 \mathrm{mg} / \mathrm{dl}$ dengan di atas $250 \mathrm{mg} / \mathrm{dl}$. Mengacu pada hasil penelitian ini di dapat bahwa kelompok 1 dan kelompok 2 masing-masing mengalami penurunan.

Perbedaanya pada tingkat penurunan untuk kelompok kadar glukosa darah di atas $250 \mathrm{mg} / \mathrm{dl}$ lebih banyak yaitu rata-rata sebesar 58,41 dibandingkan dengan kelompok di bawah $250 \mathrm{mg} / \mathrm{dl}$ mengalami penurunan rata-rata sebesar 52,77. Penderita diabetes mellitus tipe 2 dengan kadar glukosa darah di atas $250 \mathrm{mg} / \mathrm{dl}$ sudah tergolong diabetes kategori berat, apabila tidak diubah pola hidupnya dengan benar, menjaga gizi makan, dan rutin melakukan aktivitas olahraga. Maka kemungkinan terjadinya komplikasi seperti hipertensi serta jantung itu lebih beresiko tinggi. Untuk itu motivasi kesembuhan pada diabetisi di atas $250 \mathrm{mg} / \mathrm{dl}$ cenderung lebih tinggi dibandingan dengan kelompok di bawah $250 \mathrm{mg} / \mathrm{dl}$ yang kategori lebih ringan.

Motivasi tersebut misalnya lebih menjaga makanan yang dikonsumsi, melakukan diet dan rutin melakukan olahraga dan aktivitas jasmani. Dari hal ini bisa dijadikan sebab bagaimana terjadi perbedaan penurunan kadar glukosa antara dua kelompok tesebut.

Berbeda dengan kadar glukosa darah, untuk perbedaan penurunan kadar kolesterol darah penderita diabetes mellitus tipe 2 di bawah $250 \mathrm{mg} / \mathrm{dl}$ dengan di atas $250 \mathrm{mg} / \mathrm{dl}$ menunjukkan bahwa pengujian hipotesis kedua ternyata tidak ada perbedaan penurunan kadar kolesterol darah yang signifikan antara diabetisi di bawah $250 \mathrm{mg} / \mathrm{dl}$ dengan di atas $250 \mathrm{mg} / \mathrm{dl}$.

Kebenaran kajian di atas juga diperkuat dengan hasil analisis data dalam penelitian ini yaitu: kadar glukosa darah pada taraf sig diper- 
oleh sebesar $0,000<0,05$ jadi terbukti ada perbedaan penurunan kadar glukosa darah antara penderita diabetes mellitus tipe 2 di bawah 250 $\mathrm{mg} / \mathrm{dl}$ dan di atas $250 \mathrm{mg} / \mathrm{dl}$. Sedangkan kadar kolesterol darah pada taraf sig diperoleh 0,705 $>0,05$ jadi terbukti tidak ada perbedaan penurunan kadar kolesterol darah antara penderita diabetes mellitus tipe 2 di bawah $250 \mathrm{mg} / \mathrm{dl}$ dan di atas $250 \mathrm{mg} / \mathrm{dl}$.

\section{Simpulan dan Saran}

Simpulan

Berdasarkan hasil penelitian dan hasil analisis data yang telah dilakukan, diperoleh kesimpulan sebagai berikut: (1) Diayogarobik terbukti dapat meningkatkan kapasitas fisik yang meliputi fleksibilitas, kekuatan otot lengan dan kekuatan otot tungkai secara signifikan serta menurunkan kimiawi darah yang meliputi kadar glukosa darah dan kadar kolesterol darah secara signifikan pada 30 subjek penderita diabetes mellitus tipe 2, (2) a. Tidak ada perbedaan pengaruh peningkatan kapasitas fisik antara kedua kelompok penderita diabetes mellitus tipe 2 dengan kadar glukosa darah di bawah 250 $\mathrm{mg} / \mathrm{dl}$ dan penderita diabetes mellitus tipe 2 dengan kadar glukosa darah di atas $250 \mathrm{mg} / \mathrm{dl}$ setelah mengikuti progam latihan diayogarobik, (2) b. Ada perbedaan pengaruh pada penurunan kadar glukosa darah yang signifikan antara kedua kelompok penderita diabetes mellitus tipe 2 dengan kadar glukosa darah di bawah 250 $\mathrm{mg} / \mathrm{dl}$ dan penderita diabetes mellitus tipe 2 dengan kadar glukosa darah di atas $250 \mathrm{mg} / \mathrm{dl}$ dengan penurunan yang lebih tinggi pada penderita diabetes mellitus tipe 2 kadar glukosa darah di atas $250 \mathrm{mg} / \mathrm{dl}$, (2) c. Tidak ada perbedaan pengaruh penurunan kadar kolesterol darah antara kedua kelompok penderita diabetes mellitus tipe 2 dengan kadar glukosa darah di bawah $250 \mathrm{mg} / \mathrm{dl}$ dan penderita diabetes mellitus tipe 2 dengan kadar glukosa darah di atas $250 \mathrm{mg} / \mathrm{dl}$ setelah mengikuti progam latihan diayogarobik.

Saran

Berdasarkan hasil penelitian dapat disarankan hal-hal sebagai berikut: (1) Penderita diabetes mellitus tipe 2 dengan kadar glukosa darah di atas $250 \mathrm{mg} / \mathrm{dl}$ tidak perlu takut untuk melakukan olahraga atau latihan diayogarobik karena dalam penelitian ini sudah terbukti bahwa diayogarobik dapat menurunkan kadar glukosa darah dengan penurunan yang lebih tinggi pada penderita diabetes mellitus tipe 2 kadar glukosa darah di atas $250 \mathrm{mg} / \mathrm{dl}$, (2) Latihan diayogarobik memiliki pengaruh yang baik dalam menurunkan kadar glukosa darah, kadar kolesterol dan dapat meningkatkan kapasitas fisik yang meliputi fleksibilitas, kekuatan otot lengan dan kekuatan otot tungkai. Sehingga instruktur senam atau pembina olahraga dapat memilih latihan diayogarobik sebagai variasi dalam upaya menurunkan kimiawi darah dan meningkatkan kapasitas fisik agar penderita diabetes mellitus tidak merasa jenuh dengan senam-senam diabetes lainnya. (3) Instruktur senam atau pembina olahraga disarankan merancang program latihan yang tepat dan terencana sesuai dengan penyakit yang diderita masyarakat, mengingat sekarang ini banyak penyakit-penyakit yang bermunculan karena pola hidup tidak teratur mengakibatkan orangorang mudah terserang penyakit dan belum tentu suatu metode latihan sesuai atau cocok bagi semua kelompok atau semua penyakit.

\section{Daftar Pustaka}

Albright, A., et.al. (2000). Exercise and type 2 diabetes. Med Sci Sports Exerc, 32, 1345-1351.

Arikunto, Suharsimi. (2005). Metodologi penelitian. Jakarta: PT. Rineka Cipta.

Boule, N. G., et.al. (2001). Effects of exercise on glycemic control and body mass in type 2 diabetes mellitus: a meta analysis of controlled clinical trials. Jama, 286, 1218-1227.

Brunner, L. \& Suddarth, D. (2002). Buku ajar keperawatan medical bedah. Diterjemahkan oleh H. Kuncara, A. Hartono, M. Ester, Y. Asih. Edisi 8.Volume 1. Jakarta: EGC.

Giriwijoyo, H.Y.S.S. (2012). Ilmu kesehatan olahraga. Bandung: PT. Remaja Rosdakarya.

Horden, M. D., et.al. (2012). Exercise prescription for patients with type 2 diabetes and pre-diabetes: A position statement from Exercise and Sport Science Australia. Journal of Science and Medicine in Sport, 15, pp.25-31.

Lynne, Brick. (2002). Fitness aerobics. Diterjemahkan oleh Anna Agustina. Edisi 1. Cetakan 2. Jakarta: PT. Raja Grafindo Persada. 
Mahendra, Agus. (2000). Senam. Jakarta: Dirjen Dikdasmen Depdiknas.

Sani, Rachman. (2012). Yoga untuk kesehatan. Edisi Pertama. Cetakan Kedua. Semarang: Effhar Offset.

Sari, Retno Novita. (2012). Diabetes mellitus. Yogyakarta: Nuha Medika.

Sugiyono. (2008). Metode penelitian kuantitatif, kualitatifdan $R \quad \& \quad D$. Bandung: Alfabeta.
Tika Yonkuro. (2006). Profil instruktur. Yogyakarta: FIK UNY.

Sudjana. (2005). Desain dan analisis eksperimen.Edisi IV. Bandung: Tarsito.

Gardner, A. W., et. al. (2001). Exercise rehabilitation improves functional outcomes and peripheral circulation in patients with intermittent claudication: a randomized controlled trial. Journal of the American Geriatrics Society, 49, 755-761. 